\title{
ANALYZING STUDENTS' DIFFICULTIES IN MAINTAINING THEIR COHERENCE AND COHESION IN WRITING PROCESS
}

\author{
Ratu Nur Faradhibah \\ Universitas Islam Negeri Alauddin Makassar \\ faradhibahr@yahoo.com \\ Nur Aliyah Nur \\ Universitas Islam Negeri Alauddin Makassar \\ nuraliyahnur@uin-alauddin.ac.id
}

\begin{abstract}
This research concerned on writing skill, especially about coherence and cohesion as the important elements in writing. The aim of this research was to find out the students' difficulties in maintaining their coherence and cohesion in writing process. This research employed descriptive qualitative study. It was conducted in English Education Department of Tarbiyah and Teaching Science Faculty of UIN Alauddin Makassar. The subject of this research was the students of the Department of Tarbiyah of English group 1 and 2 in academic year 2016/2017. The total numbers of students were 36 students. Written test and interview was the instrument used to collect the data in this research. The findings of this research showed that there were some difficulties faced by the students in maintaining their coherence and cohesion in writing process, specifically in determining and stating their ideas, fulfilling the supporting details, and using the proper signals and spelling as well as punctuation.
\end{abstract}

Keywords: Coherence, Cohesion, Students’ Difficulties.

\section{A. INTRODUCTION}

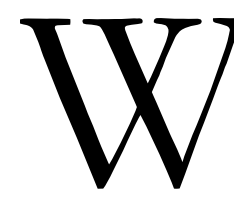

riting is one of the most difficult aspects of language skills. The ability to write involves specific skills, such as; the use of punctuation, structure of sentence, vocabulary, and organization of paragraph, but the most important thing students should pay attention before those all is their clearly main idea to deserve a good paragraph. Main idea in writing is a chains, it ties up all the sentences and makes every sentences logic. So, determining main idea before writing is an essential thing to do first because it will make all of the ideas in our paragraph arrange in a clear and logical way. It is called as coherence.

Coherence is one of the requirements of a good paragraph besides unity, cohesion, and continuity. According to Odell and Hobbs (2001), when a paragraph has coherence, the ideas are arranged in a logical progression, or an order that makes sense so that the reader moves easily from one idea to another. As one of the important aspects to be concerned, coherence becomes one of students' difficulties in writing. Most of the students often are confused with their idea. They tried to cover too many ideas instead of focusing on the single main idea and eventually, it just bounced readers around or befuddled them. In addition, students have no 


\section{Ratu Nur Faradhibah, Nur Aliyah Nur, Analyzing Students' Difficulties...}

enough knowledge to distinguish which one is the main idea and which one is just supporting idea. Therefore, when they start writing they cannot deliver a clearly thought in every paragraph. Automatically, if this happens, our writing is not coherent certainly.

Besides coherence, there is also other thing we have to notice and it cannot be separated with coherence. It is called as cohesion. Both of them are the intangible glue that holds paragraphs together. Coherence makes every sentence flows smoothly and logically while cohesion makes every sentence sticks together by using cohesive devices. Kennedy (1998) stated that cohesion refers to the ways in which texts are 'stuck together' - the ways in which sentences are linked or connected by various linguistic and semantic ties. Furthermore, Clark (2006) distinguished between coherence and cohesion, when the big parts fit, we call that good feeling coherence; when the sentences connect, we call it cohesion.

In writing, most of students ignore the using of a certain word or phrase that serve the purpose of connecting two sentences, usually by referring back to what they have previously written or said. This word and phrase is called as cohesive devices. The researcher underlines that to achieve a good cohesion, students need to know how to use cohesive devices so that their sentence in each paragraph can stick together and it easy to follow the flow of ideas, and eventually, good cohesion leads to good coherence.

As Enkvist stated (1990:126), "Writing must have surface cohesion as well as overall coherence." Therefore, reminded what Enkvist have said, the researcher decides to resolve this problem about coherence and cohesion in writing process. If they were not resolved, automatically there will be any problems appeared like students' writing lack of two important elements; coherence and cohesion. In other hand, their writing will lose its sense since the ideas do not deliver clearly and flow smoothly.

\section{B. LITERATURE REVIEW}

Several studies had been conducted related on coherence and cohesion in writing. Witte and Faigley (in Kigotho, 2002) studied ten out of ninety freshman essays that had previously been rated holistically by two readers on a four point scale. Five of the essays were selected from those given the lowest scores by both readers while five were selected from those given the highest scores. These ten essays were analyzed according to categories of error, syntactic features, as well as the types of cohesive ties. The researcher found that at the most general level of analysis, the high-rated essays had more cohesive ties than the low-rated ones. Witte and Faigley concluded that cohesion and coherence interact to a great degree, yet they noted 
that not all cohesive texts would be coherent. In addition, the use of connective links in the text must conform to a reader's expectations for particular types of texts and to his/her world knowledge. Interestingly, Witte and Faigley found that the best overall writing ability is indicated by lexical collocation (the sub-category of cohesion) which ensures writing quality. Nevertheless, their study is instructive on two counts. First, it highlights the cohesive devices which may be considered instrumental in determining writing quality, namely lexical collocation. Second, the quality of writing depends on outside factors such as the reader's background information which is beyond cohesion analysis.

Tierney and Mosenthal (1983) on the other hand, asked two classes of $12^{\text {th }}$ grade students to write essays based upon two topics. The students viewed filmstrips that had a clear topic and structure. Each student wrote two essays. The researchers found no correlation between the number of cohesive ties and coherence rankings for the essays written. They concluded that even though a count of cohesive ties helps identify cohesion in a text, a count of cohesive ties alone does not necessarily explain what makes a text coherent.

Fitzgerald and Spiegel used Halliday and Hasan's (1976) system for scoring cohesion. However, this study on cohesion and coherence differed from other studies in the way that the researchers interpreted the term "coherence" in two perspectives: one was called "coherence" itself and the other was called "quality." Therefore, in their study, they used three criteria to rate students' essays: cohesion, coherence, and writing quality. For the coherence criterion, Fitzgerald and Spiegel used a holistic rating scale which is based on the interpretation of coherence by Vandijk and Hasan (in Palmer, 1999). The quality, on the other hand, was assessed by using another holistic rating scale consisting of a range from 1-6. The results showed that there was some evidence of a significant relationship between cohesion and coherence in students' writing.

Moreover, Lee (2002) investigated the teaching of coherence to a group of 16 ESL universities students in Hong Kong. This teaching inquiry was based upon six operational definitions of coherence which included cohesion, information distribution and topical development, propositional development, modification, macrostructure, and met discourse. The teaching was incorporated into the English Communication Skills Course. The instruction lasted for about 42 hours and the students were required to write four essays throughout the course. In order to investigate whether the teaching of coherence was effective in this classroom inquiry, Lee used three sources of data: 1) pre and post revision drafts; 2) think-aloud protocol during revision; and 3) the students' teaching evaluation 


\section{Ratu Nur Faradhibah, Nur Aliyah Nur, Analyzing Students' Difficulties...}

questionnaires and interviews after the study. The results suggested that students improved the coherence of their writing and paid greater attention to the discourse level of their essays while revising the drafts. The students also thought that the teaching of coherence made them aware of what effective writing should be.

Those above are researches about coherence and cohesion and mostly, the research on cohesion described above suggests that an analysis of cohesion alone is not sufficient in determining writing quality. The two other considerations are structure and coherence. Meanwhile, the research nowadays which is doing by the researcher is only about the students' difficulties in maintaining the two elements above; coherence and cohesion.

\section{RESEARCH METHOD}

This research used descriptive qualitative research. Descriptive means that the researcher needs to collect the data and describe what happens in the field. The data that has been collected is classified based on the kinds, characteristics, or the condition. Besides collecting data, qualitative research can also find new ideas and criticisms of the process that has been done, and it can become enrichment and improvement in the learning process (Arikunto, 2013).

In this research, the researcher decided to take PBI class 1-2 as a subject because according to their writing lecturer, students in PBI class 1-2 have an interesting and creative idea when they were asked to do a writing assignment. In obtaining data, the researcher used two types of instrument, namely test and interview.

"Test is a few questions or exercises and another instrument used to measure the skill, intelligence, ability or talent had by an individual or group" (Arikunto, 2013:193). Therefore, the researcher used a writing test to know what kinds of students' difficulties in maintaining coherence and cohesion in writing process and to obtain the best efforts in maintaining coherence and cohesion in their writing. The form of the writing test that was used in this research is the researcher asked the students to write writing about 100 until 150 words in 90 minutes with a certain topic that the researcher gave to students. When the students finished their writing, the researcher collected it and then the researcher analyzed every single paragraphs of the students' writing, whether they have a coherent and cohesive writing or not.

Then, the second instrument was interview. Arikunto (2013:198) asserted that, "Interview is a dialog to acquire information from someone interviewed. Interview is used to appraise someone's condition. For example: To look for the data about variable of students' background, parents, education, attention, perception." 


\section{Volume 3, Number 02, December 2017}

In this research, the kind of interview that was used is guided interview. Consequently, before conducting an interview, the researcher needs to arrange some questions that will be asked to respondent. The researcher interviewed some students by choosing them based on their writing result to find out their difficulties in maintaining their coherence and cohesion in writing process. Then they were asked about five to seven questions related to their difficulties in maintaining their coherence and cohesion in writing process. And all of the interview results were recorded by the researcher.

In collecting data, the researcher used some procedures as follows:

1. Introduction between the researcher and students. The researcher then explained about the research to the students.

2. Then the researcher gave a certain topic to the students that would be their writing test.

3. After collecting and analyzing students' writings, the researcher interviewed some students about their difficulties when they are asked to write. In this case their difficulties in maintaining their coherence and cohesion during writing process.

4. The researcher recorded the result of interview as a data.

5. Finally, by seeing the results of the students' writing test and the results of students' interview, the researcher analyzed them to see what the students' difficulties in maintaining their coherence and cohesion during writing process in order to discover some effective and measurable ways to help students in maintaining the two important elements in their writing.

Meanwhile, in analyzing data, the researcher used qualitative analysis. Here did the researcher used Miles \& Huberman Model in analyzing data. There are four activities in analyzing data, namely data collection, data reduction, data display, and conclusion drawing/ verification. Those four types of data analysis can be explained as follows:

a. Data Collection

As mention in the sentence previously, the activity of data collection is a cyclical and interactive process. Thus, during the data collection the researcher circulated among these four steps continually in order to grasp all of the information needed in the next steps of data analysis. Accordingly, in this step, the researcher tried to find out the unripe data that will be reduced, displayed, and concluded in the next step. For this research, the researcher collected the data of the students' writing in writing classes.

b. Data Reduction 
According to Milles and Huberman (in Moleong, 2011:190), "Data reduction refers to the process of selecting, focusing, simplifying, abstracting, and transforming the data that appear in written-up field notes or transcriptions." They further point out the data reduction or data condensation process is varied in several ways, such as through selection, summary or paraphrase and being subsume in larger pattern. Simply in this step, after collecting the data of students' writing, the researcher continued the study by selecting and simplifying the data of students' writing, hence that there is no unimportant locution included in the data.

c. Data Display

The next step of data analysis is data display. After collecting and reducing the data, the researcher displayed the amassed data in organized and compressed.

The forms of qualitative data display include types of matrices, graphs, charts, or networks. The function of these types of data display is to perform accessible, compact, and organize information of the data. The researchers classified the data of the students' writing and display them in informative tables.

d. Conclusion drawing and Verification

After the data displayed in a form of table, then the researcher interpreted it and reach conclusions and verifications.

Derive from the data displayed in tables, the next step conducted by the researcher was describing and interpreting the data, so that the conclusions and verifications of the students' difficulties in maintaining their coherence and cohesion in writing process could be drawn.

\section{FINDING AND DISCUSSION}

\section{Finding}

This research collected data from written test that was given to class 1-2 of English Education Department in UIN Alauddin Makassar where this class consists of thirty eight students. But there were only thirty five students who attended the written test. The written test was held on March $5^{\text {th }} 2017$ during one hour roughly in form of writing test with a topic about dream. In this case, the researcher did not limit how many paragraphs that students should write as she just wanted to analyze what things make students difficult to maintain their coherence and cohesion in writing process.

To make a process of analyzing easily, formerly the researcher made a rubric assessment for this writing test. In the rubric assessment, the researcher attached a lot of criteria in writing which support to reach coherence and cohesion in writing process. They are about main idea, supporting detail, transition signals in use and also spelling \& punctuation. From those 
criteria, the researcher determined how coherent and cohesive the students' writing was. There are four levels of coherence and cohesion created in this rubric, they are outstanding, good work, could do better and need to improve. This rubric was made not to count a score for every student's writing or merely know about students' writing coherence and cohesion level. But it helped the researcher in order to analyze easily how coherent and cohesive the students' writing was and to find out the students' difficulties in maintaining their coherence and cohesion in writing process.

To make it more clearly, we can see the rubric of assessment as below:

Table 1

Assessment Rubric for Writing Test

\begin{tabular}{|c|c|c|c|c|}
\hline \multirow{2}{*}{ Criteria } & \multicolumn{4}{|c|}{ LEVEL OF WRITING ABILITY } \\
\hline & Outstanding & Good Work & Could Do Better & $\begin{array}{l}\text { Need to } \\
\text { Improve }\end{array}$ \\
\hline $\begin{array}{c}\text { Main } \\
\text { Idea/Topic } \\
\text { Sentence }\end{array}$ & $\begin{array}{l}\text { 1. Main idea or } \\
\text { topic } \\
\text { sentence } \\
\text { stated clearly } \\
\text { and } \\
\text { accurately. } \\
\text { 2. There is only } \\
\text { one main idea } \\
\text { or topic } \\
\text { sentence in } \\
\text { the right } \\
\text { place (either } \\
\text { in the first } \\
\text { paragraph or } \\
\text { the last } \\
\text { paragraph). }\end{array}$ & $\begin{array}{l}\text { 1. Main idea or } \\
\text { topic } \\
\text { sentence } \\
\text { stated fairly } \\
\text { clearly and } \\
\text { accurately. } \\
\text { 2. There is only } \\
\text { one main idea } \\
\text { or topic } \\
\text { sentence but } \\
\text { they are not } \\
\text { in the right } \\
\text { place (neither } \\
\text { in the first } \\
\text { paragraph } \\
\text { nor the last } \\
\text { paragraph). }\end{array}$ & $\begin{array}{l}\text { 1. Main idea or } \\
\text { topic } \\
\text { sentence } \\
\text { somewhat } \\
\text { stated unclear } \\
\text { and } \\
\text { inaccurate. } \\
\text { 2. There is } \\
\text { more than } \\
\text { one main } \\
\text { idea or topic } \\
\text { sentence and } \\
\text { they are not } \\
\text { in the right } \\
\text { place (neither } \\
\text { in the first } \\
\text { paragraph } \\
\text { nor the last } \\
\text { paragraph). }\end{array}$ & $\begin{array}{l}\text { 1. Main idea } \\
\text { or topic } \\
\text { sentence } \\
\text { stated not } \\
\text { at all clear } \\
\text { or accurate. } \\
\text { 2. Main idea } \\
\text { or topic } \\
\text { sentence } \\
\text { shows } \\
\text { complete } \\
\text { confusion }\end{array}$ \\
\hline $\begin{array}{c}\text { Supporting } \\
\text { Details }\end{array}$ & $\begin{array}{l}\text { The main idea is } \\
\text { supported by six } \\
\text { or more } \\
\text { sentences that } \\
\text { give details about } \\
\text { it. }\end{array}$ & $\begin{array}{l}\text { The main idea is } \\
\text { supported by four } \\
\text { or five sentences } \\
\text { that give details } \\
\text { about it. }\end{array}$ & $\begin{array}{l}\text { The main idea is } \\
\text { supported only by } \\
\text { one to three } \\
\text { sentences that give } \\
\text { details about it. }\end{array}$ & $\begin{array}{l}\text { There are no } \\
\text { obvious } \\
\text { supporting detail } \\
\text { sentences to } \\
\text { back up the main } \\
\text { idea. }\end{array}$ \\
\hline $\begin{array}{c}\text { Transition } \\
\text { Signals in } \\
\text { Use }\end{array}$ & $\begin{array}{l}\text { Writing uses the } \\
\text { transition signals } \\
\text { (sentence } \\
\text { connectors, } \\
\text { clause } \\
\text { connectors, and } \\
\text { others) properly } \\
\text { in every } \\
\text { paragraph and } \\
\text { manages them } \\
\text { well. }\end{array}$ & $\begin{array}{l}\text { Writing uses a } \\
\text { range of transition } \\
\text { signals } \\
\text { appropriately } \\
\text { although there } \\
\text { may be some } \\
\text { under-/over-use in } \\
\text { some paragraphs. }\end{array}$ & $\begin{array}{l}\text { Writing uses } \\
\text { transition signals } \\
\text { but in some } \\
\text { paragraphs there } \\
\text { may be faulty or } \\
\text { mechanical. }\end{array}$ & $\begin{array}{l}\text { Writing uses } \\
\text { transition signals } \\
\text { inadequate, } \\
\text { inaccurate or } \\
\text { over in every } \\
\text { paragraph. }\end{array}$ \\
\hline
\end{tabular}


Ratu Nur Faradhibah, Nur Aliyah Nur, Analyzing Students' Difficulties...

\begin{tabular}{|c|c|c|c|c|}
\hline $\begin{array}{l}\text { Spelli } \\
\text { \&Punctu }\end{array}$ & $\begin{array}{l}\text { All sentences use } \\
\text { correct spelling, } \\
\text { capital and } \\
\text { punctuation. }\end{array}$ & $\begin{array}{l}\text { Sentences have a } \\
\text { few errors in } \\
\text { spelling, capital } \\
\text { and punctuation. }\end{array}$ & $\begin{array}{l}\text { Sentences have fair } \\
\text { number error of } \\
\text { spelling, capital } \\
\text { and punctuation. }\end{array}$ & $\begin{array}{l}\text { Sentences have } \\
\text { no control over } \\
\text { spelling, capital } \\
\text { and punctuation. }\end{array}$ \\
\hline
\end{tabular}

As we can see that assessment rubric for coherence and cohesion was simply made to analyze the students' difficulties in maintaining their coherence and cohesion in writing process, whether in stating their main idea, completing their supporting details, using transition signals or having a spelling and punctuation.

Hence, after giving the writing test, the researcher started to analyze students' writing by using the assessment rubric. And the result of analyzing students' writing is sufficiently amazed. From thirty five students who attended the writing test, there are twenty five writings of students that their coherence and cohesion in could do better level while nine writings of students are in good work. And there is a writing of student in outstanding level. It means that students' coherence and cohesion level are various based on their difficulties in maintaining their coherence and cohesion in writing process.

From the result, the researcher analyzed and found that most of students are difficulties in maintaining their coherence and cohesion in writing process because firstly, they were confused about their idea. They did not know how to choose their idea and where to put it down. They had too many ideas in their head and try to spill out all of them in their writing. Therefore when they started to write, they could not state a clear and accurate main idea or topic sentence and also they place a main idea or topic sentence not in the right place, neither in the first paragraph nor in the last paragraph. In the other hand, the students also lack on fulfilling supporting details for their writing. Most of them only attached one to three sentences for supporting their main idea in every paragraph; hence, their main idea could not be explained clearly as it did not have adequate supporting details. Besides, the students were also confused about using a proper transition signal in their writing. They only knew the meaning of each transition signal without understanding how to use it properly in every sentence in their writing. At last, their writing seemed like not coherent and cohesive because they used improper transition signal.

After the two difficulties above, the researcher also found that one thing made the students feeling difficult to maintain coherence and cohesion in writing process is about the spelling and punctuation. A lot of students in writing frequently ignored this element because they thought that spelling and punctuation is not important for their writing. And it was totally wrong because spelling and punctuation is one of the crucial elements in writing and it 
Volume 3, Number 02, December 2017

influences the meaning of writing. Once they did not put a comma in a proper place, so their sentence would have an ambiguous meaning and vice versa.

\section{Discussion}

Based on the analysis of students' writing, the researcher got the data and at last, made a conclusion that there are some difficulties faced by students in maintaining their coherence and cohesion in writing process. Most of students in their writing faced some kinds of difficulties; they are about determining and stating the ideas, fulfilling the supporting details, using the proper transition signals and spelling and punctuation.

As what the researcher has stated before that the main difficulty happened in the students' writing was about determining and stating the idea. They were confused about their idea, hence they cannot state a clear and accurate topic sentence or main idea and also they lack of fulfilling supporting details or supporting sentences for their paragraph. We know that paragraph contains of three structural parts; a topic sentence or main idea, supporting sentence and a concluding sentence. If one of the three structural parts is lost, our paragraph will not be a good paragraph.

A good topic sentence will make a strong paragraph. Topic sentence needs to hook the reader, and therefore, it needs to be strong and significant. It must not simply hint or take dainty steps around our topic. According to Oshima (1998:31) that, “Topic sentence states the main idea of the paragraph. It not only names the topic of the paragraph, but it also limits the topic one or two areas that can be discussed completely in the space of a single paragraph." Therefore, a topic sentence in a paragraph is a crucial. There are some important points about topic sentence. First is topic sentence shows a complete sentence. It means topic sentence contains of subject, verb and occasionally a complement. Then, topic sentence is the most general statement in the paragraph because it gives only the main idea. It does not give any specific details. And the last is topic sentence may be in the first or the last sentence in a paragraph.

Besides topic sentence, supporting sentences are also important in a paragraph. Supporting sentences function to develop a topic sentence. Supporting sentences typically provide details and examples, facts, reasons, opinions and quotations from authorities. Supporting sentence regularly provide details and examples to help the reader understand (and agree with) the main idea. Examples can serve many purposes: we might use them to explain, to describe, to respond to assumed challenges from the reader, or simply to provide elaboration of one of our ideas (Writing in 15 minutes a Day, 2008). 


\section{Ratu Nur Faradhibah, Nur Aliyah Nur, Analyzing Students' Difficulties...}

Besides provide details and example, supporting sentence also provide facts because people as the reader tend to believe in facts, which seem to be objective and unchangeable. Because facts are not subjective, they are more easily agreed upon universally. The use of facts in any argument is likely to strengthen our position as a writer. After details, examples, and facts, then supporting sentence usually provide reasons. When we are building our main idea, we will be wise to consider all the reasons to make our reader agree with our writing. And the last is supporting sentence usually provide opinions and quotations from authorities just to convince the reader that our writing is valid.

Supporting sentences must directly explain or prove the main idea that is stated in the topic sentence. Do not include any information that does not support the topic sentence (Oshima, 1998). This case was often found in the students' writing. They write supporting sentence that are "out of the topic". These are called as irrelevant sentences.

The last part of paragraph is a concluding sentence. "A concluding sentence is not absolutely necessary; in fact, a concluding sentence is not customary for every paragraph in a writing" (Oshima, 1998:40). Concluding sentence is like a reminder for the reader about what important things or what important points in a paragraph they read.

The second difficulty happened in the students' writing was about using a proper transition signals and also spelling and punctuation whereas we know that coherence in writing can be maintained well by one of the ways like using some supporting sentences in some kind of logical order and the ideas are connected by the proper transition signals.

Transition signals are word such as first, second, next, finally, therefore and however or phrases such as in conclusion, on the other hand, and as a result. Transition signals as traffic signs that tell the reader when to go forward, turn, slow down and stop. In other words, they tell the reader when they are giving a similar idea (similarly, moreover, furthermore, in addition), an opposite idea (on the other hand, however, in contrast), an example (for example, for instance), a result (as a result), or a conclusion (in conclusion) (Oshima, 1998). If students used those transition signals appropriately, their writing will be coherence because in fact, transition signals give paragraph coherence and make it cohesive.

Based on the analysis of students' writings, the researcher found two kinds of problem related on the using transition signals. First is student's writing which used too many transition signals without noticing the appropriateness. She/he understands the meaning of each transition signals but not about the using of it. Second is student's writing which lack of transition signals. The researcher does not know exactly whether they do not know the kinds 
of transition signals or they know but they are afraid to make a mistake in using transition signals. However, a good writing requires enough transition signals to make the relationship among the ideas clear.

The other difficulty happened is about using a proper spelling and punctuation. But here, the researcher found most of writings that did a lot of mistakes in using punctuation though they also did some mistakes in spelling. The students did a misspelling for one or two words in their writing, not so much like their mistakes in using punctuation inappropriately.

There were writing with a misplaced full stop, an unnecessary comma and also there were writing without using full stop or even a comma. Unnecessary or misplaced punctuation such as a full stop or a comma is false or awkward signal that may confuse the reader (Hodges, 1984). Hence, if we tend to use too much punctuation, remember to use it appropriately. Our paragraph will be not coherent because we use too much punctuation without noticing their position. We put them in everywhere we want without considering that the meaning of our sentence in every paragraph will change and cause a misunderstanding for the reader.

\section{E. CONCLUSION AND SUGGESTION}

\section{Conclusion}

Relating to the research findings and discussions, the conclusions were students' difficulties in maintaining their coherence and cohesion in writing process mainly because they could not state a clear and accurate main idea or topic sentence or their topic sentence was not in the right place, neither in the first paragraph nor in the last paragraph. Besides, the students were also lack on fulfilling supporting details for their writing. In addition, they were also confused about using a proper transition signal in their writing. And the last is, they ignored using a proper spelling and punctuation.

\section{Suggestion}

Based on the conclusion, the researcher suggested that the students should be able to write a coherent paragraph to communicate well in writing, i.e. through writing they must be able to express their thoughts or opinions to readers. Besides, the students should be able to put sentences together in a paragraph by arranging them in logical order. Moreover, the flow of information within a paragraph should also be logical. The students should use sufficient and appropriate cohesive devices to join sentences together that keep the flow of ideas between sentences. It will help them to create a coherent paragraph. 
Ratu Nur Faradhibah, Nur Aliyah Nur, Analyzing Students' Difficulties...

\section{REFERENCES}

Arikunto. S. (2013) Prosedur Penelitian. Jakarta: Rineka Cipta.

Clark. (2006) Steps to Writing Well with Additional Readings, Wadsworth, United States of America.

Enkvist, (1990) N.E. Seven Problems in the Study of Coherence and Interpretability. New York.

Halliday and Hassan. (1976). Cohesion in English. London: Longman.

Kennedy. (1998). Harbrace College Handbook for Canadian Writers, Harbrace, Canada.

Kigotho. (2002) Writing in 15 Minutes a Day, LearningExpress, LLC, United States of America.

Lee. (2002) Coherence. Text and Context: Exploration in The Semantics and Pragmatics of Discourse. London: Longman.

Moleong, Lexy J. (2011). Metodologi Penelitian Kualitatif. Jakarta: PT. Remaja Rosdakarya.

Nur, N. A. (2015). Analyzing Vocabulary Level Of The Students'essay Writing And Academic Textbook Utilizing Lextutor. ETERNAL (English, Teaching, Learning, and Research Journal), 1(1), 15-27.

Nurpahmi.S. (2011). The contribution of Self Esteem And Self Concept Toward Writing Ability. ICOLE 2011. Universitas Islam Negeri Makassar.

Nurpahmi. S (2008). The Contribution of Self Concept and Self Esteem toward Writing Ability at the Fourth Semester Students of Language Study Program of STKIP Muhammadiyah Bone. Makassar: Graduate Program of State University of Makassar.

Odell and Hobbs. (2001). Teaching Writing Skill (Longman Handbooks for Language Teachers). Longman Group Ltd.

Oshima and Hogue. (1998). Writing Academic English. London: Longman.

Palmer. (1998) Successful College Writing: Skills-Strategies-Learning Style. Bedfort: St. Martin's.

Syams, N. F., \& Said, A. M. (2015). Error Analysis Of Word Order Used In Writing Recount Text Made By Students'at Smk Negeri 1 Pinrang. ETERNAL (English, Teaching, Learning, and Research Journal), 2(1), 25-36.

Syarifuddin, A. B. (2015). Grammatical Error Analisys In Thai Students'english Writing And Speaking At Uin Alauddin Makassar. ETERNAL (English, Teaching, Learning, and Research Journal), 1(1), 57-68.

Tierney, R., and Mosenthal, J. (1983). Cohesion and Textual Coherence. Research in The Teaching of English.tas 